\title{
Improving Linkage to and Retention in Care in Newly Diagnosed HIV-Positive Patients Using Smartphones in South Africa: Randomized Controlled Trial
}

Willem Daniel Francois Venter ${ }^{1}$, FCP(SA); Alex Fischer ${ }^{1}$, BSc; Samanta Tresha Lalla-Edward ${ }^{1}$, PhD; Jesse Coleman ${ }^{1}$, $\mathrm{PhD}$; Vincent Lau Chan ${ }^{1 \dagger}$, MPH; Zara Shubber ${ }^{2}$, PhD; Mothepane Phatsoane ${ }^{1}$, BMedSci; Marelize Gorgens ${ }^{2}$, MA; Lynsey Stewart-Isherwood ${ }^{3}$, MSc; Sergio Carmona ${ }^{3}, \mathrm{PhD}$; Nicole Fraser-Hurt ${ }^{2}, \mathrm{PhD}$

${ }^{1}$ Wits Reproductive Health and HIV Institute, University of Witwatersrand, Johannesburg, South Africa

${ }^{2}$ World Bank, World Bank Group, Washington, DC, United States

${ }^{3}$ National Health Laboratory Service, Johannesburg, South Africa

$\dagger$ deceased

\section{Corresponding Author:}

Alex Fischer, BSc

Wits Reproductive Health and HIV Institute

University of Witwatersrand

Hillbrow Health Precinct

22 Esselen St

Johannesburg, 2001

South Africa

Phone: 270113585500

Email: afischer@wrhi.ac.za

\section{Abstract}

Background: South Africa provides free antiretroviral therapy for almost 5 million people living with HIV, but only $71 \%$ of the eligible people are on treatment, representing a shortfall in the care cascade, especially among men and youth. Many developing countries have expanded access to smartphones; success in health apps raises the possibility of improving this cascade.

Objective: SmartLink is a health app for Android smartphones providing HIV-related laboratory results, information, support, and appointment reminders to engage and link patients to care. This study aimed to evaluate the ability of SmartLink to improve linkage to care for HIV-positive smartphone owners.

Methods: This study was a multisite randomized controlled trial in Johannesburg. The intervention arm received the app (along with referral to a treatment site) and the control arm received the standard of care (referral alone). Linkage to care was confirmed by an HIV-related blood test reported on the National Health Laboratory Service database between 2 weeks and 8 months after initiation.

Results: A total of 345 participants were recruited into the study; 64.9\% (224/345) of the participants were female and $44.1 \%$ (152/345) were aged less than 30 years. In addition, 46.7\% (161/345) were employed full time, 95.9\% (331/345) had at least secondary school education, and 35.9\% (124/345) were from Zimbabwe. Linkage to care between 2 weeks and 8 months was $48.6 \%(88 / 181)$ in the intervention arm versus $45.1 \%(74 / 164)$ in the control $(P=.52)$ and increased to $64.1 \%(116 / 181)$ and $61.0 \%$ $(100 / 164)(P=.55)$, respectively, after the initial 8-month period. Moreover, youth aged 18 to 30-years showed a statistically significant $20 \%$ increase in linkage to care for the intervention group.

Conclusions: Youth aged less than 30 years have been historically difficult to reach with traditional interventions, and the SmartLink app provides a proof of concept that this population reacts to mobile health interventions that engage patients in HIV care.

Trial Registration: ClinicalTrials.gov NCT02756949; https://clinicaltrials.gov/ct2/show/NCT02756949 (Archived by WebCite at http://www.webcitation.org/6z1GTJCNW)

(JMIR Mhealth Uhealth 2019;7(4):e12652) doi: 10.2196/12652 


\section{KEYWORDS}

cell phones; HIV; app; Africa; linkage to care; patient information

\section{Introduction}

\section{Background}

South Africa has the largest antiretroviral therapy (ART) program in the world, which provides free ART to approximately 4.4 million people living with HIV [1], and since its introduction in 2004, AIDS-related deaths and new HIV infections have been reduced by $58 \%$ and $46 \%$, respectively [1]. The country strategy has been created in line with international guidelines and updated with the emergence of new bodies of evidence and global initiatives [2-4].

In 2015, the 90-90-90 initiative was introduced by the Joint United Nations Programme on HIV/AIDS and the World Health Organization as a way to further decrease new infections among the population, recognizing the large impact of ART on infectiousness, while also optimizing individual health. The initiative maximizes the effect of ART coverage by emphasizing that $90 \%$ of HIV-positive people should know their status, $90 \%$ of those eligible for ART should be initiated on ART, and $90 \%$ of those on ART should achieve and maintain viral suppression [5].

South Africa has accomplished moderate success with HIV testing and viral suppression, achieving $85 \%$ and $86 \%$ success rates, respectively; however, only $71 \%$ of the people eligible for ART are on treatment [6]. It is well documented that patients, especially young people aged less than 30 years and men, are being lost to follow-up along the entire HIV care cascade, but the most significant attrition is found during the stage from HIV diagnosis to the start of treatment [7-9]. Improving this deficit is needed to ensure that patients are initiated on ART early as patients lost during linkage to care often return as late presenters when they become seriously ill. Late presenters may also continue spreading the virus, further increasing the risk of infection and threatening the 90-90-90 targets [10].

In September 2016, South Africa adopted the treatall approach for ART treatment by dropping the CD4 thresholds for ART initiation completely [11], yet patients could still expect several clinic visits before initiating ART [12]. These visits consist of initial HIV testing, followed by determination of treatment eligibility, adherence counseling, and education, as well as baseline blood tests and a physical examination before receiving the antiretrovirals [12]. Each of these visits represents a risk to the continuum of care of the newly diagnosed HIV cases and simplifying this process has been hypothesized as a way to decrease patient drop-off. Various interventions such as home-based testing and treatment and same-day initiation of ART have been tested to address this attrition, but there remains a gap [10,12-14].

The emergence of mobile health (mHealth) in developing countries has enabled some successful interventions across the continuum of HIV care, especially on the promotion of treatment adherence. With $90 \%$ of the world's population living in areas with mobile phone coverage and two-thirds of these people able to access data on their devices, mHealth provides an efficient method to engage the population [15]. Short message service (SMS) text messages and mobile apps have been used with moderate success in developing countries to improve ART adherence and appointment attendance [16-19]. South Africa has also experienced success with mHealth interventions, including the MomConnect program, which provides antenatal support through SMS and a help desk to almost 2 million pregnant mothers across the country [20].

The majority of mHealth interventions still focus on SMS text messaging, but by 2020, smartphone penetration in South Africa is expected to exceed $50 \%$ of the population [21]. The smartphones allow for data-based messaging, which should be considered for population scaling, as these platforms are much cheaper than SMS text messaging. Research surrounding linkage to care and the piloting, feasibility, and effectiveness of mHealth apps is needed to ensure that these interventions remain current as the population transition from basic phones to smartphones $[15,19,22]$.

SmartLink is an mHealth app designed to provide HIV-positive smartphone owners with their laboratory results securely and rapidly, coupled with supportive information as well as prompts to link to care. Methods and information on the app development, including the challenges and limitations of the study, have been previously published [23] and will not be discussed in detail here.

\section{Objectives}

This study presents the evaluation of SmartLink to improve linkage to care for newly diagnosed HIV-positive smartphone owners through a randomized controlled trial. Of particular interest is the linkage to care of men and youth aged less than 30 years, as these populations have been historically hard to reach with traditional interventions [7-9]. Virological suppression was also evaluated as a secondary outcome.

\section{Methods}

\section{Trial Design}

The study was designed as a multisite randomized controlled trial where newly diagnosed HIV-positive participants were approached upon having a positive HIV test and were then screened for trial eligibility. Eligible and consenting trial candidates were randomized 1:1 into either the intervention or the control arm of the study. Participants in the intervention arm were then aided with the installation and setup of SmartLink.

\section{Setting}

The inner city of Johannesburg is one of South Africa's most densely populated areas, with an estimated population of 1 million people; numerous socioeconomic challenges such as overcrowding, unemployment, crime, poverty, substance abuse, and sex work; and a high HIV prevalence [24]. The area has a well-established HIV testing and ART program, with some 
health care facilities providing ART to over 20,000 patients. However, the transient nature of the community makes it difficult to measure actual testing, linkage, and retention rates at the population level [25]. Participants were recruited at 5 public HIV testing sites ( 1 community health center, 3 clinics, and 1 tertiary hospital) from October 2015 to June 2016 and then followed up until February 2017.

\section{Participants}

Trained field workers at the 5 testing sites approached newly diagnosed HIV-positive people for trial participation after they had blood drawn for CD4 count measuring. Trial candidates were prescreened. Participants were considered for the trial if they were a resident in the area, aged 18 years and above, not pregnant, and could read English or Zulu (2 commonly understood languages in the area) [23]. Individuals were then screened for app compatibility; ineligible participants were excluded from the study if they had no active subscriber identity module card in their phone, no Android smartphone, or no data on their phone. It was discovered that the app could not be installed if the participant had insufficient RAM on their phone or if their Android version was too old (pre-version 4.2), so these parameters were also added to the exclusion criteria. Eligible participants who passed screening were then recruited into the study and randomized 1:1 into the intervention arm or the control arm using a pregenerated randomization table.

\section{Intervention}

Study staff assisted participants from the intervention arm with the installation of the SmartLink app, which was done with an Android install file and Wi-Fi dongle to allow installation at no data cost to the participants.

The app, available in English or Zulu, was designed to engage participants in their own care by directly providing them with 2 laboratory results; appointment reminders; and information about the laboratory tests, ART adherence, and HIV in general (Multimedia Appendix 1). The 2 laboratory results were CD4 count and viral load, and they were communicated in simple language. These values were also expressed visually on a color-coded scale that showed normal values and were accompanied by a short explanation of the results and guidance as to what action, if any, should be taken.

Participants randomized into the control arm received the standard of care, where participants received counseling and were referred to their local ART initiation site to collect their laboratory results and initiate appropriate treatment as needed. All participants, regardless of the study arm, were instructed to attend their local clinic for a follow-up within a few weeks of trial commencement and not to wait for the results on their phone.

\section{App Security}

The SmartLink logo, app icon, and landing page made no reference to HIV, AIDS, or health care to ensure that a participant's HIV or other health status would not be accidentally disclosed when viewing the app name or icon on a participant's phone. Furthermore, to protect confidential medical information from being available to other people, app security was modeled after local banking apps. This ensured security and privacy by employing a username, password, and a personal identification number to gain access to personal health data.

\section{Outcomes}

To capture HIV-related laboratory monitoring (our proxy for linkage to HIV care), evidence of an HIV-related laboratory test result between 2 weeks and 8 months of participant recruitment was sought. Test results were available on the National Health Laboratory Service (NHLS) database, which covers all local public facilities (but not initiation by private general practitioners or workplaces, although these provide very limited access in terms of absolute numbers), and included CD4, viral load, or creatinine clearance. Clinic visits were tracked after the initial 8 months until the completion of the follow-up in February 2017 to see if any lag to linkage to care was present in either trial arm. The viral load results were also analyzed to determine if virological suppression was achieved as a secondary outcome.

Due to these abovementioned independent databases as well as analytical data from the app developers, consolidation of these data was required. The investigators implemented a method to keep track of trial participants and their laboratory results by creating a centralized universal study dataset. To ensure intervention fidelity, this dataset was continuously monitored and evaluated by researchers to identify any potential variances [23].

\section{Data Analysis}

On the basis of the market research conducted in early 2015 at the study sites and a primary outcome measured as a second HIV-related laboratory test between 2 weeks and 8 months, a sample size of at least 1000 participants for each study arm was anticipated to measure a $20 \%$ difference in linkage to care between the intervention and control arms of each study subgroup such as young men. This was calculated based on a significance of .05 , a power of $80 \%$, and an estimated loss to follow-up of $27 \%$ (Hillbrow Community health Centre data).

Descriptive statistics were used to summarize baseline characteristics, presented as categorical data with frequency (percentage). All outcomes were compared between the intervention and control arms by linkage to care with the Pearson Chi-square test for significance. All data analyses were performed with Stata version 12.1 (StataCorp LP, College Station, TX).

The SmartLink protocol was approved by the University of Witwatersrand's Medical Human Research Ethics Committee (Certificate: M150606), the City of Johannesburg, and Gauteng's Department of Health at the provincial level and was registered in ClinicalTrials.gov (NCT02756949).

\section{Results}

\section{Participant Flow}

The participant flow diagram is shown in Figure 1. Of the 4537 individuals approached about the study, only 90 people $(2.0 \%)$ declined to participate; however, a total of 4094 people $(90.2 \%)$ 
were found to be ineligible during the prescreening and screening. The data from 8 participants in the control arm were also removed from analysis because of the erroneous sending of SMS reminders for their 6-month clinic appointment. Once removed, 164 participants (3.6\%) remained in the control arm, and 181 participants $(4.0 \%)$ remained in the intervention arm. A complete breakdown of enrollment based on inclusion and exclusion criteria has been reported [23].

Figure 1. SmartLink participant flow diagram. SMS: short message service.

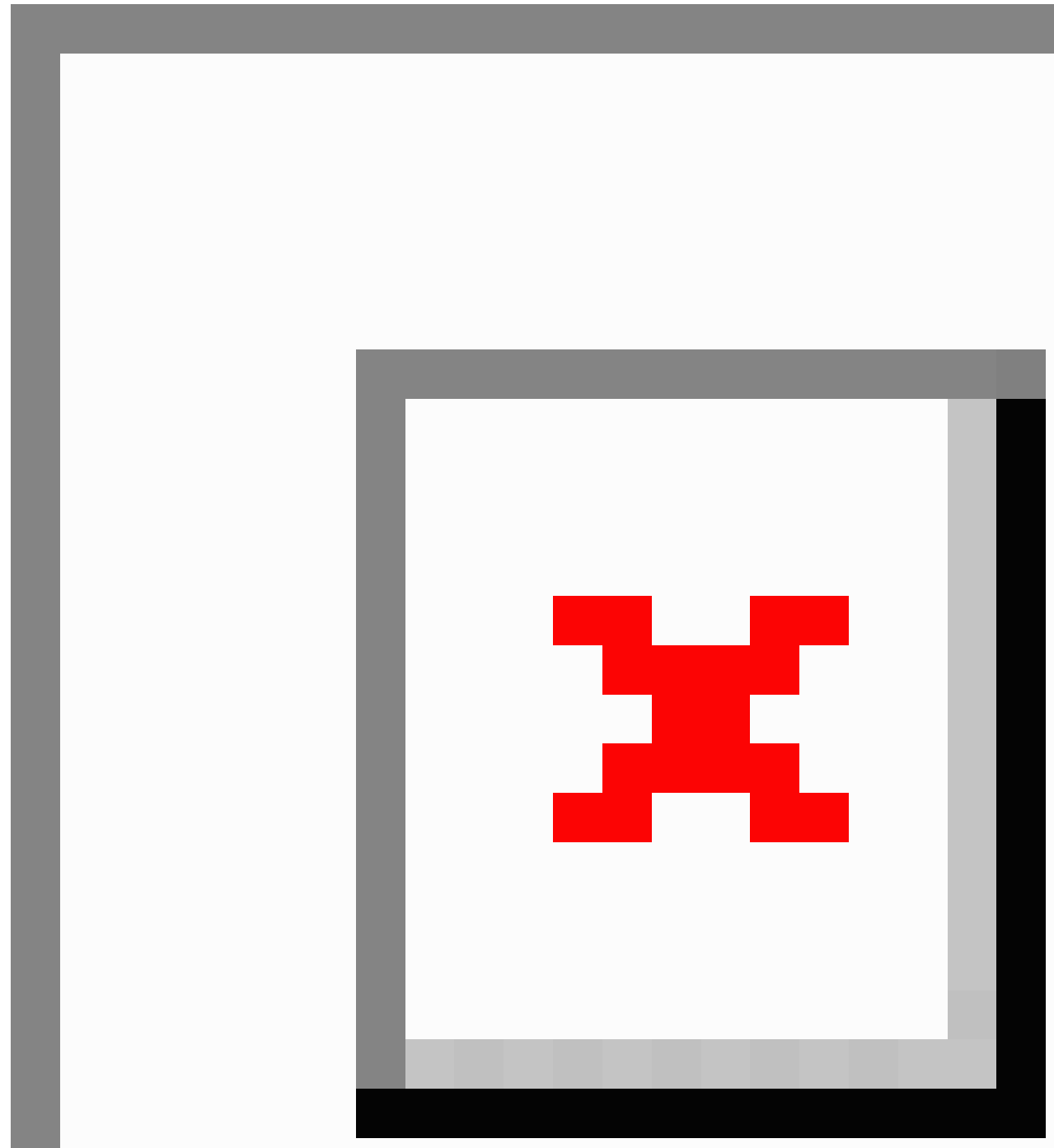


Table 1. Baseline characteristics of SmartLink trial participants.

\begin{tabular}{|c|c|c|c|}
\hline Characteristic & Control $(\mathrm{n}=164), \mathrm{n}(\%)^{\mathrm{a}}$ & Intervention $(\mathrm{n}=181), \mathrm{n}(\%)$ & Total $(\mathrm{N}=345), \mathrm{n}(\%)$ \\
\hline \multicolumn{4}{|l|}{ Sex } \\
\hline Male & $61(37.2)$ & $60(33.1)$ & $121(35.1)$ \\
\hline Female & $103(62.8)$ & $121(66.9)$ & $224(64.9)$ \\
\hline \multicolumn{4}{|l|}{ Age (years) } \\
\hline $18-30$ & $69(42.1)$ & $83(45.9)$ & $152(44.1)$ \\
\hline $31+$ & $95(57.9)$ & $98(54.1)$ & $193(55.9)$ \\
\hline \multicolumn{4}{|l|}{ Country of birth } \\
\hline South Africa & $95(57.9)$ & $103(56.9)$ & $198(57.4)$ \\
\hline Zimbabwe & $61(37.2)$ & $63(34.1)$ & $124(35.9)$ \\
\hline Other & $8(5.9)$ & $15(8.3)$ & $23(6.67)$ \\
\hline \multicolumn{4}{|l|}{ Education } \\
\hline Primary only & $6(3.7)$ & $8(4.4)$ & $14(4.1)$ \\
\hline Some secondary school & $44(26.9)$ & $51(28.2)$ & $95(27.5)$ \\
\hline Completed secondary school & $85(51.8)$ & $98(54.1)$ & $183(53.0)$ \\
\hline Attended/completed tertiary & $29(17.7)$ & $24(13.3)$ & $53(15.4)$ \\
\hline \multicolumn{4}{|l|}{ Employment status } \\
\hline Employed full time & $79(48.2)$ & $82(45.3)$ & $161(46.7)$ \\
\hline Employed part time & $22(13.4)$ & $37(20.4)$ & $59(17.1)$ \\
\hline Unemployed & $40(24.4)$ & $49(27.1)$ & $89(25.8)$ \\
\hline Self-employed & $16(9.8)$ & $10(5.5)$ & $26(7.5)$ \\
\hline Student & $7(4.4)$ & $3(1.7)$ & $10(2.9)$ \\
\hline
\end{tabular}

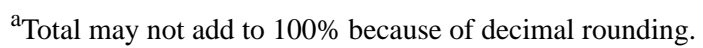

\section{Baseline Characteristics}

There were no significant differences in the baseline characteristics between the intervention and control arms (Table 1). Overall, only one-third of the participants were male (35.1\%) and nearly half $(44.1 \%)$ were youth aged less than 30 years. Almost half of the participants were employed full time (46.7\%) and the majority had at least attended secondary school (95.9\%). In addition, $57.4 \%$ of the participants were South African and just over one-third $(35.9 \%)$ were from Zimbabwe. These baseline characteristics reflect the demographics of inner-city Johannesburg, where many migrants from Zimbabwe have settled and become part of the local population. These migrants are often well educated and possibly more likely to be employed than South Africans living in the inner city.

Although the 2 trial arms were well balanced in terms of participants' characteristics, there was, however, an important bias as to which demographic groups entered the trial because of the smartphone eligibility criteria [23]. Those with less education, those earning less, and those unemployed or underemployed are less likely to have smartphones to be eligible for the study [23].

\section{Primary Outcome: Linkage to Care}

This study called for a sample size of 2000 total participants; however, because of several challenges and limitations outlined, recruitment numbers were much lower than anticipated at 345 [23].

\section{Total Cohort}

Linkage to HIV care between 2 weeks and 8 months was just under $50 \%$ (45.1\% control vs $48.6 \%$ intervention; $P=.516$ ) and increased to just over $60 \% \quad(61.0 \%$ control vs $64.1 \%$ intervention; $P=.551$ ) after the initial 8 -month period (Table 2).

\section{Males}

The male population, which was of specific interest, showed a slightly higher (but not statistically significant) linkage to care with the app between 2 weeks and 8 months (47.5\% control vs $55.0 \%$ intervention; $P=.412)$, but after 8 months, both these values were similar, approximately $66 \%(67.2 \%$ control vs $66.7 \%$ intervention; $P=.949$ ).

\section{Youth Aged Between 18 and 30 Years}

Despite the small sample size, a statistically significant difference was seen with youth aged between 18 and 30 years. Linkage to care between 2 weeks and 8 months was approximately $20 \%$ higher for youth with the app (31.9\% control vs $53.0 \%$ intervention; $P=.009)$, and this remained true after 8 months as well $(50.7 \%$ control vs $69.9 \%$ intervention; $P=.016$; Table 2). 
Table 2. Linkage to care.

\begin{tabular}{|c|c|c|c|c|c|c|c|c|c|c|}
\hline \multirow[t]{2}{*}{ Group } & \multicolumn{5}{|c|}{ Linked to care for 2 weeks to 8 months } & \multicolumn{5}{|c|}{ Ever linked to care } \\
\hline & $\mathrm{NLC}^{\mathrm{a}}, \mathrm{n}(\%)$ & $\mathrm{LC}^{\mathrm{b}}, \mathrm{n}(\%)$ & Total, $\mathrm{n}$ & Pearson $\chi^{2}$ & $P$ value & NLC, n (\%) & $\mathrm{LC}, \mathrm{n}(\%)$ & Total, n & Pearson $\chi^{2}$ & $P$ value \\
\hline \multicolumn{11}{|l|}{ Total cohort } \\
\hline Control & $90(54.9)$ & $74(45.1)$ & 164 & 0.4 & .52 & $64(39.0)$ & $100(61.0)$ & 164 & 0.4 & .55 \\
\hline Intervention & $93(51.4)$ & $88(48.6)$ & 181 & 0.4 & .52 & $65(35.9)$ & $116(64.1)$ & 181 & 0.4 & .55 \\
\hline Total & $183(53.0)$ & $162(47.0)$ & 345 & 0.4 & .52 & $129(37.4)$ & $216(62.6)$ & 345 & 0.4 & .55 \\
\hline \multicolumn{11}{|l|}{ Males } \\
\hline Control & $32(52.5)$ & $29(47.5)$ & 61 & 0.7 & .41 & $20(32.8)$ & $41(67.2)$ & 61 & 0.0 & .95 \\
\hline Intervention & $27(45.0)$ & $33(55.0)$ & 60 & 0.7 & .41 & $20(33.3)$ & $40(66.7)$ & 60 & 0.0 & .95 \\
\hline Total & $59(48.4)$ & $63(51.6)$ & 121 & 0.7 & .41 & $40(33.1)$ & $81(66.9)$ & 121 & 0.0 & .95 \\
\hline \multicolumn{11}{|l|}{ Females } \\
\hline Control & $58(56.3)$ & 45 (43.7) & 103 & 0.1 & .79 & $44(42.7)$ & $59(57.3)$ & 103 & 0.7 & .40 \\
\hline Intervention & 66 (54.6) & $55(45.5)$ & 121 & 0.1 & .79 & 45 (37.2) & $76(62.8)$ & 121 & 0.7 & .40 \\
\hline Total & $124(55.4)$ & $100(44.6)$ & 224 & 0.1 & .79 & $89(39.7)$ & $135(60.3)$ & 224 & 0.7 & .40 \\
\hline \multicolumn{11}{|c|}{ Youth aged between 18 and 30 years } \\
\hline Control & $47(68.1)$ & $22(31.9)$ & 69 & 6.8 & .01 & $34(49.3)$ & $35(50.7)$ & 69 & 5.8 & .02 \\
\hline Intervention & $39(47.0)$ & $44(53.0)$ & 83 & 6.8 & .01 & $25(30.1)$ & $58(69.9)$ & 83 & 5.8 & .02 \\
\hline Total & $86(56.6)$ & $66(43.4)$ & 152 & 6.8 & .01 & $59(38.8)$ & $93(61.2)$ & 152 & 5.8 & .02 \\
\hline \multicolumn{11}{|c|}{ Aged over 30 years } \\
\hline Control & $43(45.3)$ & $52(54.7)$ & 95 & 1.9 & .17 & $30(31.6)$ & $65(68.4)$ & 95 & 1.8 & .18 \\
\hline Intervention & $54(55.1)$ & $44(44.9)$ & 98 & 1.9 & .17 & $40(40.8)$ & $58(59.2)$ & 98 & 1.8 & .18 \\
\hline Total & $97(50.3)$ & 96 (49.7) & 193 & 1.9 & .17 & $70(36.3)$ & $123(63.7)$ & 193 & 1.8 & .18 \\
\hline
\end{tabular}

${ }^{\mathrm{a}} \mathrm{NLC}$ : not linked to care.

${ }^{b}$ LC: linked to care.

Table 3. Viral load suppression.

\begin{tabular}{|c|c|c|c|c|c|}
\hline \multirow[t]{2}{*}{ Study group } & \multicolumn{5}{|c|}{ Virally suppressed } \\
\hline & Yes, n (\%) & No, n $(\%)$ & Total, n (\%) & Pearson $\chi^{2}$ & $P$ value \\
\hline Intervention & $28(63.6)$ & $16(36.4)$ & $44(100.0)$ & 0.2 & .66 \\
\hline Control & $23(59.0)$ & $16(41.0)$ & $39(100.0)$ & 0.2 & .66 \\
\hline Total & $51(61.5)$ & $32(38.6)$ & $83(100.0)$ & 0.2 & .66 \\
\hline
\end{tabular}

\section{Secondary Outcome: Viral Load Suppression}

For participants who had viral load tests in the NHLS database, virological suppression was assessed as an outcome. As recruitment numbers were much lower than anticipated, participant results were also low, and no statistically significant results were reached; however, these values are presented for completeness (Table 3). As of February 2017, a total of 83 participants had viral load tests that could be used for analysis, 39 out of $164(23.8 \%)$ from the control arm and 44 out of 181 (24.3\%) from the intervention arm. With viral load suppression defined as less than 400 copies/mL, $59.0 \%$ of the control arm and $63.6 \%$ of the intervention arm experienced suppression; however, the $P$ value of .663 negated any significance.

\section{Discussion}

\section{Principal Findings}

Although this was the first evaluation using a smartphone-enabled app to support linkage to HIV care in Africa, as far as we are aware, the study outcomes were limited due to being underpowered as a result of complications and limitations surrounding app compatibility. As a proof of concept, the SmartLink app worked as anticipated; however, the smartphone specifications required for installation excluded over $90 \%$ of candidates who volunteered to participate in the study. This is unfortunately a common trend in mHealth studies, where many interventions show generally positive results; however, they are often inconclusive or are not substantial 
enough when extrapolated out to a broader population or scaled up $[16,26]$.

Although this study demonstrated that app-linked information and prompting can lead to increased linkage to care, the specific technology was not evaluated. The SmartLink app provided patients with laboratory results, information, and appointment reminders, but the relative efficacy of these specific components could not be explored. Despite the challenges in trial enrolment, one population of interest, youth aged 18 to 30 years, showed a statistically significant benefit of the app. This subpopulation experienced a $20 \%$ increase in linkage to care for the app group, and this is encouraging as HIV patients in this age group have historically been very difficult to engage with traditional interventions [8]. In South Africa, this population is $16 \%$ more likely to own a smartphone and $19 \%$ more likely to access the internet with their phone than their parents [27]. The high smartphone ownership coupled with our evidence of increased linkage in care strongly suggests that mHealth apps for engagement in care should be considered for this age group.

This demographic will become more and more familiar with technology, reinforcing the need to create a strong body of evidence surrounding these mHealth interventions. For children aged 9 to 17 years, $80 \%$ have access to internet on a smartphone and $84 \%$ own their own device. This generation is growing up with the internet, social media, and apps and already possesses the same mobile skills set as their parents, with children even surpassing them with knowledge about creating media and installing apps [28]. Future studies should focus on tailoring mHealth interventions toward youth, while also providing an opportunity to standardize counseling and support communications from health care providers [29].

\section{Conclusions}

This proof-of-concept study has demonstrated that SmartLink can significantly increase linkage to care for youth aged 18 to 30 years; however, further evaluation with larger samples is required to recommend such an intervention for programmatic rollout. This research is of timely importance as demand for entry-level smartphones (sub-US \$100) in developing countries had led to over 400 million smartphone units being sold in the first quarter of 2018 alone [30]. As smartphone penetration increases and prices decrease, new innovations such as using quick response code technology coupled with patient-held smartcards can allow for information to be transferred without internet access or data [31]. During this shift, mHealth apps should also be considered for incorporation into multifaceted interventions as bundling apps with SMS text messaging, phone calls, or in-person communications could be a way to optimally engage patients while app familiarity and technology continue to improve [32].

\section{Limitations}

Secondary outcomes, such as ART initiation rates, feasibility, satisfaction, and participants' knowledge, could not be evaluated because of the limitations, as outlined by Venter et al in 2018 [23]. Analytics on app use by participants also could not be evaluated because of complications in data collection between the devices and the back-end analytics software. Essentially, data exchange between the relevant systems could not be achieved during the trial, limiting the scope of log-in analytics to counts of app openings only. Finally, we acknowledge the limitations of the trial in terms of generalizability, as already mentioned. The eligibility criteria lead to a selected patient group. For instance, a relatively high proportion of Zimbabwean patients and more educated patients were better able to qualify for the trial.

\title{
Acknowledgments
}

The authors would like to acknowledge all the patients and health care workers who participated in the study, National Health Laboratory Service (NHLS) that facilitated in the data collection, and the World Bank for their technical and financial assistance.

\section{Conflicts of Interest}

None declared.

\section{Multimedia Appendix 1}

Screenshots of the SmartLink app.

[PNG File, 916KB-Multimedia Appendix 1]

\author{
Multimedia Appendix 2 \\ CONSORT-EHEALTH checklist (V 1.6.1).
}

[PDF File (Adobe PDF File), 551KB-Multimedia Appendix 2]

\section{References}

1. UNAIDS. Geneva; 2018. URL: http://www.unaids.org/sites/default/files/media asset/unaids-data-2018 en.pdf [accessed 2018-10-22] [WebCite Cache ID 73LxdKdmv]

2. National Department of Health (2018). Annual Performance Plan 2018/19-2020/21. Pretoria, South Africa. ISBD: 9780621461749. 
3. World Health Organization. Geneva; 2015 Nov 25. Guideline on When to Start Antiretroviral Therapy and on Pre-Exposure Prophylaxis for HIV URL: https://www.who.int/sorry/ [accessed 2019-02-18] [WebCite Cache ID 76IBOdg89]

4. World Health Organization. Congo; 2016. WHO Country Cooperation Strategy 2016-2020 URL: https://apps.who.int/iris/ bitstream/handle/10665/255007/ccs_zaf_2016_2020.pdf?sequence=1\&isAllowed=y

5. AIDS. UNAIDS. Geneva; 2017. Global AIDS Update URL: http://www.unaids.org/en/resources/documents/2017/ \%202017 data book [accessed 2019-02-18] [WebCite Cache ID 76IBqoFe0]

6. The Human Sciences Research Council. 2018. The Fifth South African National HIV Prevalence, Incidence, Behaviour and Communication Survey, 2017: HIV Impact Assessment Summary Report URL: http://www.hsrc.ac.za/uploads/ pageContent/9234/SABSSMV Impact Assessment Summary ZA ADS cleared PDFA4.pdf [accessed 2019-02-18] [WebCite Cache ID 76IEzX9V0]

7. NACOSA - Networking HIV \& AIDS Community of Southern Africa NPC. 2016. Adherence Guidelines for HIV, TB and NCDs URL: https://www.nacosa.org.za/wp-content/uploads/2016/11/Integrated-Adherence-Guidelines-NDOH.pdf [accessed 2018-07-08] [WebCite Cache ID 6rmrZXOMi]

8. Maheu-Giroux M, Tanser F, Boily M, Pillay D, Joseph SA, Bärnighausen T. Determinants of time from HIV infection to linkage-to-care in rural KwaZulu-Natal, South Africa. AIDS 2017 Dec 24;31(7):1017-1024 [FREE Full text] [doi: 10.1097/QAD.0000000000001435] [Medline: 28252526]

9. Takarinda KC, Harries AD, Shiraishi RW, Mutasa-Apollo T, Abdul-Quader A, Mugurungi O. Gender-related differences in outcomes and attrition on antiretroviral treatment among an HIV-infected patient cohort in Zimbabwe: 2007-2010. Int J Infect Dis 2015 Jan;30:98-105 [FREE Full text] [doi: 10.1016/j.ijid.2014.11.009] [Medline: 25462184]

10. Rosen S, Fox MP. Retention in HIV care between testing and treatment in sub-Saharan Africa: a systematic review. PLoS Med 2011 Jul;8(7):e1001056 [FREE Full text] [doi: 10.1371/journal.pmed.1001056] [Medline: 21811403]

11. Motsoaledi A. Bhekisisa Centre for Health Journalism. \#AIDS2016: Health Minister Aaron Motsoaledi admits that 'key leaders were in denial' URL: https://bhekisisa.org/article/

2016-07-15-aids2016-health-minister-aaron-motsoaledi-admits-that-key-leaders-were-in-denial/ [accessed 2018-10-22] [WebCite Cache ID 73M7Xp6zp]

12. Long LC, Maskew M, Brennan AT, Mongwenyana C, Nyoni C, Malete G, et al. Initiating antiretroviral therapy for HIV at a patient's first clinic visit: a cost-effectiveness analysis of the rapid initiation of treatment randomized controlled trial. AIDS 2017 Jul 17;31(11):1611-1619 [FREE Full text] [doi: 10.1097/QAD.0000000000001528] [Medline: 28463879]

13. Iwuji CC, Orne-Gliemann J, Larmarange J, Okesola N, Tanser F, Thiebaut R, ANRS 12249 TasP trial group. Uptake of home-based HIV testing, linkage to care, and community attitudes about ART in rural KwaZulu-Natal, South Africa: descriptive results from the first phase of of the ANRS 12249 TasP cluster-randomised trial. PLoS Med 2016 Aug;13(8):e1002107 [FREE Full text] [doi: 10.1371/journal.pmed.1002107] [Medline: 27504637]

14. Larson BA, Schnippel K, Brennan A, Long L, Xulu T, Maotoe T, et al. Same-day CD4 testing to improve uptake of HIV care and treatment in South Africa: point-of-care is not enough. AIDS Res Treat 2013;2013:941493 [FREE Full text] [doi: 10.1155/2013/941493] [Medline: 23956850]

15. Stephani V, Opoku D, Quentin W. A systematic review of randomized controlled trials of mHealth interventions against non-communicable diseases in developing countries. BMC Public Health 2016 Dec 15;16(1):572-510 [FREE Full text] [doi: 10.1186/s12889-016-3226-3] [Medline: 27417513]

16. Mbuagbaw L, Mursleen S, Lytvyn L, Smieja M, Dolovich L, Thabane L. Mobile phone text messaging interventions for HIV and other chronic diseases: an overview of systematic reviews and framework for evidence transfer. BMC Health Serv Res 2015 Jan 22;15:33 [FREE Full text] [doi: 10.1186/s12913-014-0654-6] [Medline: 25609559]

17. Finitsis DJ, Pellowski JA, Johnson BT. Text message intervention designs to promote adherence to antiretroviral therapy (ART): a meta-analysis of randomized controlled trials. PLoS One 2014 Feb;9(2):e88166 [FREE Full text] [doi: 10.1371/journal.pone.0088166] [Medline: 24505411]

18. Kanters S, Park JJ, Chan K, Socias ME, Ford N, Forrest JI, et al. Interventions to improve adherence to antiretroviral therapy: a systematic review and network meta-analysis. Lancet HIV 2017 Dec;4(1):e31-e40. [doi: 10.1016/S2352-3018(16)30206-5] [Medline: 27863996]

19. Perera AI, Thomas MG, Moore JO, Faasse K, Petrie KJ. Effect of a smartphone application incorporating personalized health-related imagery on adherence to antiretroviral therapy: a randomized clinical trial. AIDS Patient Care STDS 2014 Nov;28(11):579-586 [FREE Full text] [doi: 10.1089/apc.2014.0156] [Medline: 25290556]

20. Seebregts C, Dane P, Parsons AN, Fogwill T, Rogers D, Bekker M, et al. Designing for scale: optimising the health information system architecture for mobile maternal health messaging in South Africa (MomConnect). BMJ Glob Health 2018 Apr;3(Suppl 2):e000563 [FREE Full text] [doi: 10.1136/bmjgh-2017-000563] [Medline: 29713506]

21. GSMA Intelligence. 2017. The Mobile Economy Sub-Saharan Africa 2018 URL: https://www.gsmaintelligence.com/ research/?file $=809 \mathrm{c} 442550 \mathrm{e} 5487 \mathrm{f} 3 \mathrm{~b} 1 \mathrm{~d} 025 \mathrm{fdc} 70 \mathrm{e} 23 \mathrm{~b} \&$ download

22. Fox M, Rosen S, Geldsetzer P, Bärnighausen T, Negussie E, Beanland R. Interventions to improve the rate or timing of initiation of antiretroviral therapy for HIV in sub-Saharan Africa: meta-analyses of effectiveness. J Int AIDS Soc 2016;19(1):20888 [FREE Full text] [doi: 10.7448/IAS.19.1.20888] [Medline: 27507249] 
23. Venter W, Coleman J, Chan VL, Shubber Z, Phatsoane M, Gorgens M, et al. Improving linkage to HIV care through mobile phone apps: randomized controlled trial. JMIR Mhealth Uhealth 2018 Jul 17;6(7):e155 [FREE Full text] [doi: 10.2196/mhealth.8376] [Medline: $\underline{30021706]}$

24. Tshuma N, Muloongo K, Setswe G, Chimoyi L, Sarfo B, Burger D, et al. Potential barriers to rapid testing for human immunodeficiency virus among a commuter population in Johannesburg, South Africa. HIV AIDS (Auckl) 2015;7:11-19 [FREE Full text] [doi: 10.2147/HIV.S71920] [Medline: 25565898]

25. Venter WF, Coleman J, Lau CV, Phatsoane M. World Bank Group. 2017. Smart Linkage to Care : Evaluation Report URL: http://documents.worldbank.org/curated/en/374611542662090016/pdf/ WP-132214-SmartLtCEvaluationReportUpdateNovFINAL.pdf [accessed 2019-02-19] [WebCite Cache ID 76INX0Ipd]

26. Aranda-Jan C, Mohutsiwa-Dibe N, Loukanova S. Systematic review on what works, what does not work and why of implementation of mobile health (mHealth) projects in Africa. BMC Public Health 2014 Feb 21;14:188 [FREE Full text] [doi: 10.1186/1471-2458-14-188] [Medline: 24555733]

27. Poushter J. Pew Research Center.: Pew Global; 2016 Feb 22. Smartphone Ownership and Internet Usage Continues to Climb in Emerging Economies URL: http://www.pewglobal.org/2016/02/22/ smartphone-ownership-and-internet-usage-continues-to-climb-in-emerging-economies/ [accessed 2018-10-22] [WebCite Cache ID 73MDoUknh]

28. LSE Research Online. 2016 Sep. Global Kids Online South Africa: barriers, opportunities and risks. A glimpse into South African children's internet use and online activities URL: http://eprints.lse.ac.uk/71267/2/

GKO_Country-Report_South-Africa_CJCP_upload.pdf [accessed 2019-02-19] [WebCite Cache ID 76IOCZ6gF]

29. Section 27. How we can improve HIV testing and counselling URL: https://section27.org.za/2012/04/4568/ [accessed 2018-10-22] [WebCite Cache ID 73MEGfPQe]

30. Costello K, Hippold S. Gartner. 2018. Gartner Says Worldwide Sales of Smartphones Returned to Growth in First Quarter of 2018 URL: https://www.gartner.com/newsroom/id/3876865 [accessed 2018-10-22] [WebCite Cache ID 73MEkAOAz]

31. Gbadamosi SO, Eze C, Olawepo JO, Iwelunmor J, Sarpong DF, Ogidi AG, et al. A patient-held smartcard with a unique identifier and an mHealth platform to improve the availability of prenatal test results in rural Nigeria: demonstration study. J Med Internet Res 2018 Jan 15;20(1):e18 [FREE Full text] [doi: 10.2196/jmir.8716] [Medline: 29335234]

32. Mugo PM, Wahome EW, Gichuru EN, Mwashigadi GM, Thiong'o AN, Prins HA, et al. Effect of text message, phone call, and in-person appointment reminders on uptake of repeat HIV testing among outpatients screened for acute HIV infection in Kenya: a randomized controlled trial. PLoS One 2016 Apr 14;11(4):e0153612 [FREE Full text] [doi: 10.1371/journal.pone.0153612] [Medline: 27077745]

\section{Abbreviations \\ ART: antiretroviral therapy \\ mHealth: mobile health \\ NHLS: National Health Laboratory Service \\ SMS: short message service}

Edited by G Eysenbach; submitted 30.10.18; peer-reviewed by K Chigudu, S Gbadamosi, E Green; comments to author 06.12.18;
revised version received 21.12.18; accepted 03.01.19; published 02.04.19
Please cite as:
Venter WDF, Fischer A, Lalla-Edward ST, Coleman J, Lau Chan V, Shubber Z, Phatsoane M, Gorgens M, Stewart-Isherwood L,
Carmona S, Fraser-Hurt N
Improving Linkage to and Retention in Care in Newly Diagnosed HIV-Positive Patients Using Smartphones in South Africa: Randomized
Controlled Trial
JMIR Mhealth Uhealth 2019;7(4):e12652
URL: https://mhealth.jmir.org/2019/4/e12652/
doi: $10.2196 / 12652$
PMID: $\underline{30938681}$

(C)Willem Daniel Francois Venter, Alex Fischer, Samanta Tresha Lalla-Edward, Jesse Coleman, Vincent Lau Chan, Zara Shubber, Mothepane Phatsoane, Marelize Gorgens, Lynsey Stewart-Isherwood, Sergio Carmona, Nicole Fraser-Hurt. Originally published in JMIR Mhealth and Uhealth (http://mhealth.jmir.org), 02.04.2019. This is an open-access article distributed under the terms of the Creative Commons Attribution License (https://creativecommons.org/licenses/by/4.0/), which permits unrestricted use, distribution, and reproduction in any medium, provided the original work, first published in JMIR mhealth and uhealth, is properly 
cited. The complete bibliographic information, a link to the original publication on http://mhealth.jmir.org/, as well as this copyright and license information must be included. 